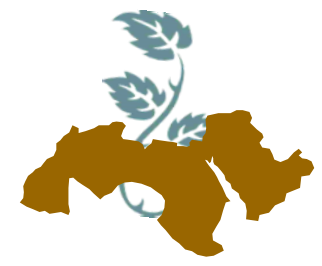

Arab Univ.

J. Agric. Sci.,

Ain Shams Univ., Cairo

Special Issue, 26(2A), 1239-1250, 2018

\title{
EXOGENOUS APPLIED PUTRESCINE ELEVATE DROUGHT TOLERANCE OF SUNFLOWER PLANTS BY MODIFYING OF SOME PHYSIO-BIOCHEMICAL PARAMETERS
}

\author{
Faisal $^{1}$, A.; M.F.M. Ibrahim ${ }^{2}$ and S.A. Shehata ${ }^{2}$ \\ 1- Biology Dept., Fac. of Education and Sci., Sana'a Univ., Sana'a, Yemen \\ 2- Agric. Botany Dept., Fac. of Agric., Ain Shams Univ., Cairo, Egypt \\ Corresponding Author: Said Shehata, Dept. of Agric. Botany, Fac. of Agric., Ain Shams Univ., Cairo, Egypt. \\ E-mail said shehata@agr.asu.edu.eg
}

Keywords: Sunflower putrescine; Polyamines; Water stress and Physio-biochemical parameters

\section{ABSTRACT}

Field Experiments were conducted at the Experimental Farm, Faculty of Agriculture, Ain Shams University, Shoubra El-Kheima, Egypt during 2014 and 2015 seasons to evaluate the effect of foliar spray of putrescine (Put) at 0.1 and $0.2 \mathrm{mM}$ on growth and some physio-biochemical compounds of drought stressed sunflower. Putrescine application could be mitigate the negative effect of drought by increasing leaf relative water content (LRWC), proline, total soluble sugars, $\mathrm{K}$ and $\mathrm{Ca}$ concentrations of sunflower leaves. Correlation coefficient revealed that LRWC was inversely proportional to proline concentration on the one hand and directly proportional to $\mathrm{K}^{+}$and $\mathrm{Ca}^{++}$concentrations on the other hand. The modification of physio-biochemical parameters by Put treatments led to increase plant growth and seed-oil yield of sunflower under drought stress.

\section{INTRODUCTION}

Sunflower (Helianthus annuus L) is one the most important oil crops in the world; it is rich in the nutritional value for human because its oil consists of $90 \%$ oleic and $10 \%$ linoleic acids whereas, protein content of the seed ranged from $20-30 \%$ in addition to the presence of vitamin A, B vitamins, iron, calcium, nitrogen and phosphorus (Arshad and Amjad, 2012). Occasionally, sunflower plant encounter water stress particularly in arid and semi- arid land under Egyptian climatic conditions.
Drought Stress is considered the most environmental challenges which represent a serious threat to agriculture worldwide, it cause a considerable loss in the yield for many economical crops. As a result of drought stress, plants respond by changing some physio-biochemical compounds either on cell or molecular levels (Smirnoff, 1993; Abbaspour et al 2012; Ibrahim et al 2015). These responses include substantially changes in the content of reactive oxygen species (ROS) and activity of antioxidant enzymes (Ibrahim and Ibrahim, 2016a). Moreover, drought stress affects leaf water status, pigments and stomatal conductance leading to inhibit photosynthesis (Farooq et al 2009; Saraswathi and Paliwal, 2011).

Several compounds have been used to ameliorate drought stress and improve plant growth and productivity. Polyamines (PAs) are considered as plant growth regulators with a wide range of effects, they are involved in many processes of plant growth and development including DNA replication and cell division (Galston and Sawhney, 1990); regulating of senescence (Lahiri et al 2004) and mineral nutrition (Tamai et al 1999). Additionally, it was well documented that PAs play an important role in protecting plants from various adverse environmental conditions including salinity (Suping et al 2007); heavy metals (Groppa et al 2007) and drought stress (Farooq et al 2009). These responses may be due to many reasons such as their cross talk interactions with several hormonal pathways especially ABA (Alcázar et al 2010) or their ability on adjusting osmosis (Aziz et al 1999) and scavenging of free radicals (Velikova et al 1998) under abiotic stress conditions. 
Generally, polyamines include di-amine putrescine (Put), tri-amine spermidine (Spd) and tetraamine spermine (Spm). The di-amine putrescine (Put) is considered the most common PAs, it is directly produced from the non-proteinogenic amino acid ornithine through the activity of ornithine decarboxylase (ODC) or indirectly from arginine through arginine decarboxylase (ADC) (Alcázar et al 2010).

Previous study of Ibrahim et al (2016b) revealed that sunflower plants were negatively affected under water stress. Therefore, the purpose of this work was to test the effects of the exogenous application of Put on growth, yield and some physio-biochemical substances which could be acquired drought-tolerance of sunflower plant; additionally, the role of Put in drought tolerance mechanisms could further be understood.

\section{MATERIAL AND METHODS}

\section{Experimental layout}

Two field experiments were carried out during the seasons of 2014 and 2015 respectively at the Experimental Farm, Faculty of Agriculture, Ain Shams University, Shoubra El-Kheima, Egypt to investigate the effect of foliar application by putrescine (Put) at $0,0.1$ and $0.2 \mathrm{mM}$ on sunflower plants under two different irrigation levels. The experimental soil was clay loam and its chemical analysis was shown in Table (1). Also, field capacity $(\mathrm{FC})$, wilting point and the available water of the experimental soil were shown in Table (2). The physico-chemical and mechanical analysis were determined according to the method of Jackson (1967).

Table 1. Some chemical analyses of the experimental soil

\begin{tabular}{|c|c|c|c|c|c|c|c|c|c|c|}
\hline \multirow{2}{*}{ Depth of soil } & \multirow{2}{*}{$\mathbf{p H}$} & \multirow{2}{*}{$\begin{array}{c}\mathrm{EC} \\
\mathbf{d s} / \mathbf{m}\end{array}$} & \multicolumn{4}{|c|}{ Soluble cations meq $\mathbf{L}$} & \multicolumn{4}{c|}{ Soluble anions $\mathbf{m e q} / \mathbf{L}$} \\
\cline { 5 - 11 } & & $\mathbf{N a}^{+}$ & $\mathbf{K}^{+}$ & $\mathbf{C a}^{++}$ & $\mathbf{M g}^{++}$ & $\mathbf{C O}_{3}{ }^{2-}$ & $\mathbf{H C O}_{3}{ }^{-}$ & $\mathbf{C l}^{-}$ & $\mathbf{S O}_{4}{ }^{-2}$ \\
\hline $0-60 \mathrm{~cm}$ & 7.12 & 0.976 & 2.48 & 0.89 & 4.49 & 1.9 & 0 & 3.45 & 2.38 & 3.93 \\
\hline
\end{tabular}

Table 2. Field capacity (FC), wilting point and available water of the experimental soil during the seasons of 2014 and 2015

\begin{tabular}{|c|c|c|c|c|c|c|}
\hline \multirow{2}{*}{$\begin{array}{c}\text { Depth of } \\
\text { soil }\end{array}$} & \multicolumn{3}{|c|}{2014} & \multicolumn{3}{c|}{2015} \\
\cline { 2 - 7 } & FC \% & $\begin{array}{c}\text { Wilting } \\
\text { point \% }\end{array}$ & $\begin{array}{c}\text { Available } \\
\text { water \% }\end{array}$ & FC \% & $\begin{array}{c}\text { Wilting } \\
\text { point \% }\end{array}$ & $\begin{array}{c}\text { Available } \\
\text { water \% }\end{array}$ \\
\hline $0-60 \mathrm{~cm}$ & 23.48 & 13.43 & 10.05 & 23.85 & 13.57 & 10.28 \\
\hline
\end{tabular}

Seeds of the local cultivar (Sakha 53) were purchased from The Agriculture Research Center, Giza, Egypt. The seeds were sown on the $1^{\text {st }}$ and $5^{\text {th }}$ of June in both seasons of 2014 and 2015 respectively. The area of the experimental unit was 9 $\mathrm{m}^{2}(3 \times 3 \mathrm{~m})$ with $60 \mathrm{~cm}$ apart rows and plant spacing $20 \mathrm{~cm}$, an alley $(2 \mathrm{~m})$ wide was left as a border between both irrigation levels. The experiments were arranged in split plot design with three replicates. The applied irrigation levels were assigned in the main plots and the foliar application were distributed in the sub-plots.

\section{Cultural management and irrigation procedure}

Fertilization, disease and pest control programs were followed according to the recommendations of the Egyptian Ministry of Agriculture. Two levels of irrigation were started applied 20 days after sowing date. The well-watered and droughtstressed plants have received 55-65 and $25-35 \%$ from FC, respectively. To maintain the water level at the examined range during the whole experiment; samples of soil at depth $0-60 \mathrm{~cm}$ were taken regularly by an Auger T-Handle every 2 days to determine the soil moisture content by the weight method. The samples were dried at $105^{\circ} \mathrm{C}$ for 24 hours and re-weighting until it reached a constant weight. The percentage of soil moisture was measured by using the following equation:

\section{Soil moisture\% = [(weight before drying- weight after drying)/ weight after drying] ${ }^{*} 100$}

\section{Foliar application and sampling}



plants by modifying of some physio-biochemical parameters

The foliar application of distilled water as a control and putrescine (Put) at 0.1 and $0.2 \mathrm{mM}$ were sprayed twice at 30 and 50 days from sowing (DAS). Every time, Tween 20 at $0.05 \mathrm{ml} / \mathrm{L}$ was added as a wetting agent. Plant samples at 60 days old were randomly selected from the inner rows to study the growth parameters and biochemical constituents. Mature heads of plants were harvested at 95 DAS to estimate the yield and its components in both seasons.

\section{Growth parameters and relative water content}

The leaves and stem fresh weight were determined at sampling (60 days after sowing) immediately by digital balance. To determine the dry weight for both organs, the samples were dried in air-forced ventilated oven at $70{ }^{\circ} \mathrm{C}$ until a constant weight (A.O.A.C., 2000). Leaf relative water content (LRWC) was determined according to Unyayar et al (2004). Leaf discs from 10 leaves were weighted (FW) and placed immediately in distilled water for $2 \mathrm{~h}$ at $25^{\circ} \mathrm{C}$ and then their turgid weights (TW) were recorded. The samples were then dried in an oven at $110{ }^{\circ} \mathrm{C}$ for $24 \mathrm{~h}$ (DW). Relative water content (LRWC) was calculated by using the following formula:

\section{$L R W C=(F W-D W) /(T W-D W)^{*} 100$}

\section{Biochemical constituents}

Organic osmolytes (proline - total soluble sugars)

Proline concentration was determined by the method of ninhydrin reagent as described by Bates et al (1973). Total soluble sugars were estimated by the phenol sulphoric acid method as described by Chow and Landhausser (2004).

\section{Leaf Mineral Concentration}

Dry leaves were grounded and digested using sulphuric acid and hydrogen peroxide. Leaf concentrations of $\mathrm{K}$ and $\mathrm{Ca}$ were determined according to Cottenie et al (1982).

\section{Yield and its components}

The heads were bagged at early stage of seed development to avoid the damage that could be occurred by birds during the maturity. Seeds weight/head and the estimated yield of seeds (ton/fed) were estimated in the two seasons.

\section{Oil percentage and its yield $\left(\mathrm{kg}_{\mathrm{fed}}{ }^{-1}\right)$}

Oil percentage of seeds was extracted by hexane using soxhlet apparatus according to A.O.A.C. (2000). Oil yield $\left(\mathrm{kg} \mathrm{fed}^{-1}\right)$ was calculated by using the following formula:

\section{Oil yield $\left(\mathrm{kg} \mathrm{fed}^{-1}\right)=$ [average of oil percentage * average of seed yield (kg. $\left.\left.\mathrm{fed}^{-1}\right)\right] / 100$.}

\section{Statistical analysis}

Data were analyzed using SAS Institute Inc, (1988). The means were calculated and Duncan's test $(P \leq 0.05)$ was used to determine significant differences between means; correlation coefficient was also performed.

\section{RESULTS AND DISCUSSION}

\section{Changes in leaf water status}

As shown in Table (3), it can be observed that water deficit caused a significant $(P \leq 0.05)$ decrease in leaf relative water content (LRWC) in comparison with the well-watered plants in both seasons. These results are in harmony with those obtained by Ibrahim et al (2016b). The foliar application of Put at 0.1 or $0.2 \mathrm{mM}$ led to remarkable increments in LRWC in both seasons. The highest significant $(P \leq 0.05)$ values were achieved by the treatment of Put at $0.2 \mathrm{mM}$ in comparison with the controls in the two seasons, respectively.

Under different treatments, it was obvious that put at $0.2 \mathrm{mM}$ increased LRWC under both investigated irrigation levels. These increases reached the level of significance $(P \leq 0.05)$ under wellwatered conditions in the second season and under drought stress in both seasons respectively in comparison with the controls.

These findings could be attributed to the direct effect of Put on maintaining the membrane integrity; it has been suggested that polyamines (PAs) have a distinct ability on stabilizing the structure of the membranes of the plant cell during biotic and/or abiotic stresses (Tassoni et al 1996; Schuber, 1989). These effects could achieve through their antioxidant and acid neutralizing properties (Borell et al 1997; Zhao and Yang, 2008). 
Table 3. Effect of foliar application of putrescine (Put) at $0,0.1$ and $0.2 \mathrm{mM}$ on Leaf relative water content (LRWC) (\%) of sunflower plants at 60 days after sowing under two different irrigation levels during the seasons of 2014 and 2015

\begin{tabular}{|c|c|c|c|c|c|c|}
\hline \multirow{2}{*}{$\begin{array}{c}\text { Putrescine } \\
\text { concentration }\end{array}$} & \multicolumn{3}{|c|}{2014} & \multicolumn{3}{c|}{ 2015 } \\
\cline { 2 - 7 } & $\begin{array}{c}\text { Well- } \\
\text { watered }\end{array}$ & $\begin{array}{c}\text { Water - } \\
\text { stressed }\end{array}$ & Mean & $\begin{array}{c}\text { Well- } \\
\text { watered }\end{array}$ & $\begin{array}{c}\text { water - } \\
\text { stressed }\end{array}$ & Mean \\
\hline Control (distilled water) & $80.02 \mathrm{a}$ & $66.04 \mathrm{C}$ & $73.03 \mathrm{~B}$ & $81.16 \mathrm{~b}$ & $63.89 \mathrm{~d}$ & $72.53 \mathrm{C}$ \\
$0.1 \mathrm{mM}$ & $82.12 \mathrm{a}$ & $67.26 \mathrm{bc}$ & $74.69 \mathrm{AB}$ & $81.92 \mathrm{ab}$ & $68.93 \mathrm{c}$ & $75.43 \mathrm{~B}$ \\
$0.2 \mathrm{mM}$ & $83.02 \mathrm{a}$ & $69.37 \mathrm{~b}$ & $76.20 \mathrm{~A}$ & $84.48 \mathrm{a}$ & $70.76 \mathrm{c}$ & $77.62 \mathrm{~A}$ \\
\hline Mean & $\mathbf{8 1 . 7 2} \mathbf{A}^{\prime}$ & $\mathbf{6 7 . 5 6} \mathbf{B}^{\prime}$ & & $\mathbf{8 2 . 5 2} \mathbf{A}$ & $\mathbf{6 7 . 8 6} \mathbf{B}^{\prime}$ & \\
\hline
\end{tabular}

Means followed by different letters are significantly different at $P \leq 0.05$ according to Duncan's multiple range test

\section{Changes in growth parameters}

Data presented in Table (4) show that water stress resulted in a significant $(P \leq 0.05)$ decrease in all studied growth parameters including the fresh and dry weight of sunflower leaves and stem plants in both seasons, respectively. These results are consistent with those reported by Ibrahim et al (2016b). The negative effect of water stress on plant growth could be attributed to the disturbance for several of physiological processes viz., inhibits photosynthesis in the higher plants by decreasing coupling factor and ATP (Tezara et al 1999). Moreover, it can impair the stomatal conductance and limit $\mathrm{CO}_{2}$ access (Taiz and Zeiger, 2002). Also, the efficient water supply is important for cell turgor and cell wall extensibility which required for normal plant growth and development (Blum, 2011).

On the other hand, the foliar application of putrescine (Put) at 0.1 or $0.2 \mathrm{mM}$ led to significant $(P \leq 0.05)$ increases for all investigated growth parameters compared to the control plants in both seasons. Moreover, no significant differences were observed between the effect of both investigated Put concentrations on growth parameters except on stem fresh weight in the second season and stem dry weight in the first one. Generally, the highest significant $(P \leq 0.05)$ values were obtained by the high concentration of the applied Put at 0.2 $\mathrm{mM}$. The positive effect of Put on the growth parameters could be explained by that polyamines
$\left(\mathrm{PA}_{\mathrm{s}}\right)$ have been implicated in a wide range of metabolic, growth and development processes in plants such as cell division, embryogenesis, morphogenesis, seed germination, DNA replication and responses against environmental and biotic stresses (Tiburcio et al 1993; Kaur-Sawhney et al 2003 and Groppa et al 2007).

Under all possible treatments, it can be noticed that the foliar treatment of Put at $0.2 \mathrm{mM}$ gave at mostly the highest significant $(P \leq 0.05)$ increases in growth parameters compared to the control plants under both examined irrigation levels in both seasons. These results could be attributed to that Put may improve the water status (Table, 3 ) and photosynthesis of plants under both examined irrigation levels in this study.

\section{Changes in the organic osmolytes}

Data presented in Table (5) show that water stress increased significantly $(P \leq 0.05)$ proline and soluble sugars concentrations compared to the well-watered plants in both seasons. This response may be associated with stress tolerance because the accumulation of these organic solutes can regulate the osmotic potential of cells leading to improve the absorption of water under drought stress (Misra and Gupta 2005; Zhang et al 2010 and Ibrahim et al 2016b). Furthermore, these compatible solutes can also protect the enzymes and macromolecules of plant cell from oxidation by ROS (Farooq et al 2012). 
Table 4. Effect of foliar application of putrescine (Put) at $0,0.1$ and $0.2 \mathrm{mM}$ on some growth parameters of sunflower plants at 60 days after sowing under two different irrigation levels during the seasons of 2014 and 2015

\begin{tabular}{|c|c|c|c|c|c|c|}
\hline \multirow[b]{2}{*}{$\begin{array}{c}\text { Putrescine } \\
\text { concentration }\end{array}$} & \multicolumn{3}{|c|}{2014} & \multicolumn{3}{|c|}{2015} \\
\hline & $\begin{array}{c}\text { Well- } \\
\text { watered }\end{array}$ & $\begin{array}{l}\text { Water - } \\
\text { stressed }\end{array}$ & Mean & $\begin{array}{c}\text { Well- } \\
\text { watered }\end{array}$ & $\begin{array}{l}\text { Water - } \\
\text { stressed }\end{array}$ & Mean \\
\hline \multicolumn{7}{|c|}{ Leaves fresh weight (g. plant $^{-1}$ ) } \\
\hline Control (distilled water) & $199.54 \mathrm{~b}$ & $86.75 \mathrm{~d}$ & 143.15 B & $187.70 \mathrm{~b}$ & $113.32 \mathrm{c}$ & 150.51 B \\
\hline $0.1 \mathrm{mM}$ & $261.61 \mathrm{a}$ & $117.55 \mathrm{c}$ & $189.58 \mathrm{~A}$ & $248.19 \mathrm{a}$ & $122.87 \mathrm{c}$ & $185.53 \mathrm{~A}$ \\
\hline $0.2 \mathrm{mM}$ & $244.67 \mathrm{a}$ & $135.94 \mathrm{c}$ & $190.30 \mathrm{~A}$ & $226.57 \mathrm{a}$ & $127.96 \mathrm{c}$ & $177.27 \mathrm{~A}$ \\
\hline Mean & $235.27 A^{\prime}$ & 113.41 B' & & $220.82 A^{\prime}$ & 121.39 B' & \\
\hline \multicolumn{7}{|c|}{ Leaves dry weight (g. plant ${ }^{-1}$ ) } \\
\hline Control (distilled water) & $23.78 \mathrm{~b}$ & $16.23 \mathrm{~d}$ & $20.00 \mathrm{~B}$ & $24.49 \mathrm{c}$ & $19.20 \mathrm{~d}$ & $21.85 B$ \\
\hline $0.1 \mathrm{mM}$ & $33.34 \mathrm{a}$ & $20.95 c$ & $27.15 \mathrm{~A}$ & $31.74 b$ & $21.80 \mathrm{~cd}$ & $26.77 \mathrm{~A}$ \\
\hline $0.2 \mathrm{mM}$ & $33.93 \mathrm{a}$ & $22.41 \mathrm{bc}$ & $28.17 \mathrm{~A}$ & $35.24 \mathrm{a}$ & $21.62 \mathrm{~cd}$ & $28.43 \mathrm{~A}$ \\
\hline Mean & $30.35 A^{\prime}$ & 19.86 B' $^{\prime}$ & & $30.49 \mathrm{~A}^{\prime}$ & 20.87 B' & \\
\hline \multicolumn{7}{|c|}{ Stem fresh weight (g. plant $^{-1}$ ) } \\
\hline Control (distilled water) & $359.35 \mathrm{~b}$ & $230.69 \mathrm{c}$ & 295.02 B & $312.43 \mathrm{c}$ & $261.93 \mathrm{~d}$ & $287.18 \mathrm{C}$ \\
\hline $0.1 \mathrm{mM}$ & 454.73 a & $301.17 b$ & $377.95 \mathrm{~A}$ & $378.65 \mathrm{~b}$ & $296.81 \mathrm{c}$ & $337.73 \mathrm{~B}$ \\
\hline $0.2 \mathrm{mM}$ & $495.40 \mathrm{a}$ & $309.08 \mathrm{~b}$ & $402.24 \mathrm{~A}$ & $464.13 \mathrm{a}$ & $307.99 \mathrm{c}$ & $386.06 \mathrm{~A}$ \\
\hline Mean & $436.49 \mathrm{~A}^{\prime}$ & 280.32 B' & & $385.07 \mathrm{~A}^{\prime}$ & $288.91 B^{\prime}$ & \\
\hline \multicolumn{7}{|c|}{ Stem dry weight (g. plant $^{-1}$ ) } \\
\hline Control (distilled water) & $97.27 \mathrm{c}$ & $79.40 \mathrm{~d}$ & $88.33 \mathrm{C}$ & $114.91 b$ & $85.63 \mathrm{c}$ & $100.27 \mathrm{~B}$ \\
\hline $0.1 \mathrm{mM}$ & $135.96 \mathrm{~b}$ & $91.13 \mathrm{~cd}$ & $113.55 \mathrm{~B}$ & $147.42 \mathrm{a}$ & $88.32 \mathrm{c}$ & $117.87 \mathrm{~A}$ \\
\hline $0.2 \mathrm{mM}$ & $155.96 \mathrm{a}$ & $93.01 \mathrm{~cd}$ & $124.48 \mathrm{~A}$ & $151.04 \mathrm{a}$ & $91.67 \mathrm{c}$ & $121.36 \mathrm{~A}$ \\
\hline Mean & 129.73 A' & 87.85 B' & & $137.79 \mathrm{~A}^{\prime}$ & 88.54 B' & \\
\hline
\end{tabular}

Means followed by different letters are significantly different at $P \leq 0.05$ according to Duncan's multiple range test

Table 5. Effect of foliar application of putrescine (Put) at $0,0.1$ and $0.2 \mathrm{mM}$ on proline and soluble sugars concentrations of sunflower leaves at 60 days after sowing under two different irrigation levels during the seasons of 2014 and 2015

\begin{tabular}{|c|c|c|c|c|c|c|}
\hline \multirow[b]{2}{*}{$\begin{array}{c}\text { Putrescine } \\
\text { concentration }\end{array}$} & \multicolumn{3}{|c|}{2014} & \multicolumn{3}{|c|}{2015} \\
\hline & $\begin{array}{c}\text { Well- } \\
\text { watered }\end{array}$ & $\begin{array}{c}\text { Water- } \\
\text { stressed }\end{array}$ & Mean & $\begin{array}{c}\text { Well- } \\
\text { watered }\end{array}$ & $\begin{array}{c}\text { Water- } \\
\text { stressed }\end{array}$ & Mean \\
\hline \multicolumn{7}{|c|}{ Proline ( $\mu$ mol. $g^{-1}$ d.wt) } \\
\hline Control (distilled water) & $18.44 \mathrm{c}$ & $76.02 \mathrm{a}$ & $47.23 \mathrm{~A}$ & $21.51 \mathrm{c}$ & $80.96 \mathrm{a}$ & $51.24 \mathrm{~A}$ \\
\hline $0.1 \mathrm{mM}$ & $15.59 \mathrm{c}$ & $66.47 \mathrm{~b}$ & $41.03 \mathrm{~B}$ & $16.41 \mathrm{c}$ & $61.00 \mathrm{~b}$ & $38.71 \mathrm{~B}$ \\
\hline $0.2 \mathrm{mM}$ & $14.67 \mathrm{c}$ & $62.48 \mathrm{~b}$ & $38.55 \mathrm{~B}$ & $15.48 \mathrm{c}$ & $57.87 \mathrm{~b}$ & $36.68 \mathrm{~B}$ \\
\hline Mean & 16.22 B' & $68.32 \mathrm{~A}^{\prime}$ & & $17.80 \mathrm{~B}^{\prime}$ & $66.61 \mathrm{~A}^{\prime}$ & \\
\hline \multicolumn{7}{|c|}{ Soluble sugars (mg.g ${ }^{-1}$ d.wt) } \\
\hline Control (distilled water) & $64.27 \mathrm{~d}$ & $82.62 \mathrm{~b}$ & $73.45 \mathrm{~B}$ & $63.96 \mathrm{c}$ & $80.85 a b$ & $72.41 \mathrm{~B}$ \\
\hline $0.1 \mathrm{mM}$ & $72.76 \mathrm{c}$ & $86.03 \mathrm{ab}$ & $79.40 \mathrm{~A}$ & $75.82 \mathrm{~b}$ & $83.94 \mathrm{ab}$ & $79.88 \mathrm{~A}$ \\
\hline $0.2 \mathrm{mM}$ & $75.20 \mathrm{c}$ & $91.36 \mathrm{a}$ & $83.28 \mathrm{~A}$ & $81.32 \mathrm{ab}$ & $85.49 \mathrm{a}$ & $83.40 \mathrm{~A}$ \\
\hline Mean & 70.75 B' & $86.67 A^{\prime}$ & & $73.70 \mathrm{~B}^{\prime}$ & 83.42 A' & \\
\hline
\end{tabular}

Means followed by different letters are significantly different at $P \leq 0.05$ according to Duncan's multiple range test 
Regarding the effect of foliar application of Put at 0.1 or $0.2 \mathrm{mM}$ on the concentration of proline and soluble sugars in sunflower leaves; the results revealed that there was a significant $(P \leq 0.05)$ decrease in proline whereas; an opposite trend was observed in regard to soluble sugars compared to the control in both seasons. Several previous reports have been indicated that the exogenous application of polyamines (PAs) could reduce the endogenous accumulation of proline under diverse environmental conditions (Jiménez-Bremont et al 2006; Karimi, 2016 and Hanafy Ahmed, 2017). This effect might be attributed to increase the activity of proline dehydrogenase and degradation of proline to glutamate. This response seems to be beneficial in supporting mitochondrial oxidative phosphorylation and increasing the consuming of $\mathrm{O}_{2}$ leading to reduce the oxidative stress and permit the plants to adapt under stress conditions (Hare and Cress 1997).

Conversely, increasing the soluble sugars in response to the exogenous application of put had been proved in many previous investigations (Saleem et al 2008 and Hanafy Ahmed, 2017).

This effect could be explained by that the exogenous PAs can rapidly enter the chloroplast (He et al 2002) and play an important role in protecting the photosynthetic apparatus from the adverse effects of environmental stresses (Navakoudis et al 2003 and Gupta et al 2012).

Under all different possible treatments, it is obvious that there was a significant $(P \leq 0.05)$ decrease in the proline content under water shortage by the foliar treatments of Put at 0.1 or $0.2 \mathrm{mM}$ compared to the untreated plants in both seasons. This result revealed that Put may play a pivotal role in the metabolic pathway of proline under drought stress more than normal conditions. On the other hand, soluble sugars were higher under both examined irrigation levels with both applications of Put compared to the controls. The highest significant $(P \leq 0.05)$ values were obtained by the treatment of Put at $0.2 \mathrm{mM}$ compared to the control under the same level of water supply. These results reflected that applied Put may have a positive effect on the photosynthesis and carbohydrate metabolism regardless the available water supply.

\section{Changes in the minerals}

As shown in Table (6), both $\mathrm{K}$ and $\mathrm{Ca}$ concentrations were significantly $(P \leq 0.05)$ reduced by exposing to water stress compared to the well- watered plants in both seasons. This response may be attributed to decrease the diffusion of ions and their movements from the soil to the roots under water deficit conditions; this relationship was confirmed earlier in the previous publication by Ibrahim et al (2016b).

Concerning, the influence of applied Put on leaf $\mathrm{K}$ and $\mathrm{Ca}$ concentration, it can be observed that generally, the concentration of both elements was increased as affected by the foliar application of Put. The highest significant $(P \leq 0.05)$ increases were achieved by the high examined concentration of Put at $0.2 \mathrm{mM}$ compared to the control in both seasons. The possible role of PAs in maintaining the nutrients balance in plant tissues had been reviewed earlier in many species under diverse environmental conditions. The distribution of $\mathrm{K}^{+}$, $\mathrm{Na}^{+}$and $\mathrm{Cl}^{-}$in different organs of cucumber seedlings were greatly affected under $\mathrm{NaCl}$ stress (Suping et al 2007). Furthermore, they can regulate the absorption and translocation of toxic ions in maize (Jiang et al 2000) and spring wheat (Iqbal and Ashraf, 2005). These effects may be attributed to stabilizing cell membranes and affecting their proteins which act as channels, carriers and pumps for ions. In this respect, Zhao and Qin (2004) reported that applied PAs increased the activities of root tonoplast $\mathrm{H}^{+}$-ATPase, $\mathrm{H}^{+}$-PPase and $\mathrm{Na}^{+} / \mathrm{H}^{+}$transporter in barley seedlings under salt stress whereas; Roy et al (2005) found that there was an increase in the activity of $\mathrm{H}^{+}$-ATPase of the plasma membrane of rice under salt stress.

The interaction between the irrigation level and the treatments of Put showed that the treatment of Put at $0.2 \mathrm{mM}$ under both irrigation levels revealed significant $(P \leq 0.05)$ increases in the concentrations of leaf $\mathrm{K}$ and $\mathrm{Ca}$ compared to the controls in the two seasons. Increasing these minerals by Put applications may be more convenient for adjusting water status and improving the growth and different physiological processes than the untreated plants in both seasons. For instance, under water stress, it was noticed that PAs can target and inhibit the inward $\mathrm{K}^{+}$channels in guard cells whereas; at the same time they can increase the cytosolic $\mathrm{Ca}^{2+}$ by activating some specific ion channels on the membranes. This effect may induce stomatal closure under water stress conditions through different signaling pathways (Gilroy et al 1990 and Alcázar et al 2010) and has been considered to be an adaptation response to protecting plants from drought. 
Exogenous applied putrescine elevate drought tolerance of sunflower plants by modifying of some physio-biochemical parameters

Table 6. Effect of foliar application of putrescine (Put) at $0,0.1$ and $0.2 \mathrm{mM}$ on leaf $\mathrm{K}$ and Ca concentrations (\%) of sunflower plants at 60 days after sowing under two different irrigation levels in the seasons of 2014 and 2015

\begin{tabular}{|c|c|c|c|c|c|c|}
\hline \multirow{2}{*}{$\begin{array}{l}\text { Putrescine } \\
\text { concentration }\end{array}$} & \multicolumn{3}{|c|}{2014} & \multicolumn{3}{|c|}{2015} \\
\hline & $\begin{array}{c}\text { Well- } \\
\text { watered }\end{array}$ & $\begin{array}{c}\text { water - } \\
\text { stressed }\end{array}$ & Mean & $\begin{array}{c}\text { Well- } \\
\text { watered }\end{array}$ & $\begin{array}{c}\text { water - } \\
\text { stressed }\end{array}$ & Mean \\
\hline \multicolumn{7}{|c|}{ K (\%) } \\
\hline Control (distilled water) & $1.92 \mathrm{bc}$ & $1.38 \mathrm{~d}$ & $1.65 \mathrm{~B}$ & $1.90 \mathrm{~b}$ & $1.34 \mathrm{~d}$ & $1.62 \mathrm{~B}$ \\
\hline $0.1 \mathrm{mM}$ & $2.13 \mathrm{ab}$ & $1.66 \mathrm{~cd}$ & $1.89 \mathrm{AB}$ & $2.04 \mathrm{~b}$ & $1.58 \mathrm{c}$ & $1.81 \mathrm{AB}$ \\
\hline $0.2 \mathrm{mM}$ & $2.45 \mathrm{a}$ & $1.77 \mathrm{c}$ & $2.11 \mathrm{~A}$ & $2.33 \mathrm{a}$ & $1.60 \mathrm{c}$ & $1.97 \mathrm{~A}$ \\
\hline \multirow{2}{*}{\multicolumn{7}{|c|}{$1.50 \mathrm{~B}^{\prime}$}} \\
\hline & & & & & & \\
\hline Control (distilled water) & $1.375 c$ & $1.054 \mathrm{e}$ & $1.215 \mathrm{C}$ & $1.507 \mathrm{ab}$ & $1.129 \mathrm{c}$ & $1.318 \mathrm{~B}$ \\
\hline $0.1 \mathrm{mM}$ & $1.493 b$ & $1.241 \mathrm{~d}$ & $1.367 \mathrm{~B}$ & $1.605 \mathrm{a}$ & $1.353 \mathrm{bc}$ & $1.479 \mathrm{AB}$ \\
\hline $0.2 \mathrm{mM}$ & $1.647 \mathrm{a}$ & $1.479 \mathrm{~b}$ & $1.563 \mathrm{~A}$ & $1.727 \mathrm{a}$ & $1.532 \mathrm{ab}$ & $1.629 \mathrm{~A}$ \\
\hline Mean & $1.51 A^{\prime}$ & $1.26 B^{\prime}$ & & $1.61 \mathrm{~A}^{\prime}$ & 1.34B' & \\
\hline
\end{tabular}

Means followed by different letters are significantly different at $P \leq 0.05$ according to Duncan's multiple range test

\section{Interaction relationships between LRWC and different osmolytes}

Under water stress, the relationship between water status of plants and adjusting their contents from wide diverse osmolytes had been well documented in many previous studies. This response could help plants to improve the absorption of water under drought stress (Zhang et al 2010).

Data presented in Table (7) revealed that there were significant correlations among leaf relative water content (LRWC) and its contents from proline, $\mathrm{K}$ and $\mathrm{Ca}$, whereas; this relationship was not evident with soluble sugars. Since the increase in LRWC was inversely proportional to proline and directly to $\mathrm{K}$ and $\mathrm{Ca}$ respectively. These findings indicated that sunflower plants might maintain their water status and adjustment osmotic potential through modifying proline, $\mathrm{K}$ and $\mathrm{Ca}$ more than soluble sugars under water deficit conditions. These results were in harmony with those suggested by Ibrahim et al (2016b). On the other hand, it is obvious that the accumulation of soluble sugars under water shortage may play an important role in the signaling pathways (Smeekens et al 2010) which are also essential in the adaptive mechanisms to stress (Ramel et al 2009).

Urthermore, it is known that the availability of water is considered the main factor limiting absorption and translocation of minerals from the roots to the shoot systems in plants therefore water stress decrease transpiration rate and consequently the translocation of minerals through xylem pathway was reduced (da Silva et al 2011). This effect could explain the significant direct correlations between LRWC on the one hand and the concentration of both minerals $\mathrm{K}$ and $\mathrm{Ca}$ on the other hand.

Concerning, the other interaction relationships, it can be noticed that there was a significant inverse correlation between proline and the concentration of both minerals $\mathrm{K}$ and $\mathrm{Ca}$;in addition, it was found a significant direct relationship between the two minerals ( $\mathrm{K}$ and $\mathrm{Ca}$ ) and each other. these results indicated that there were many close linkages between these traits. These responses may protect plants and help them to improve their tolerance mechanisms against drought stress.

\section{Seed and Oil yield attributes}

As shown in Table (8), all studied parameters related to the seed and oil yield of sunflower plants including seed weight $\left(\right.$ g.head $\left.^{-1}\right)$, seed yield $\left(\right.$ ton.fed ${ }^{-1}$ ), oil percentage in seeds and oil yield $\left({\left.\mathrm{kg} . \mathrm{fed}^{-1}\right)}^{-1}\right.$ were decreased significantly $(P \leq 0.05)$ under water deficit compared to the controls in both seasons. These results were in accordance with many previous studies (Ali et al 2009; Alahdadi et al 2011; Ibrahim et al 2016b). Drought stress can alter the source-sink relationships between different plant organs (Farooq et al 2009). Besides, it can affect the biosynthesis and metabolic pathways of lipids in plants (Anh et al 1985; Gigon et al 2004 and Okazaki \& Saito, 2014). Additionally, water stress caused a lot of negative effects on plant growth, LRWC and absorption of nutrients included $\mathrm{K}$ and $\mathrm{Ca}$. 
Table 7. Combined analysis for the correlation coefficient between leaf relative water content (LRWC) and its content from osmolytes (proline, soluble sugars, $\mathrm{K}$ and $\mathrm{Ca}$ ), in sunflower plants at 60 DAS as affected by the foliar application of putrescine at $0,0.1$ and $0.2 \mathrm{mM}$ under two irrigation levels in the seasons of 2014 and 2015

\begin{tabular}{|c|c|c|c|c|}
\hline Variable & RWC & Proline & Soluble sugars & K \\
\hline RWC & - & & & \\
Proline & $(-) 0.996^{* *}$ & - & - & \\
Soluble sugars & $(-) 0.676^{\text {NS }}$ & $(+) 0.710^{\text {NS }}$ & $(-) 0.420^{\text {NS }}$ & - \\
K & $(+) 0.944^{* *}$ & $(-) 0.922^{* *}$ & $(-) 0.204^{\text {NS }}$ & $(+) 0.918^{* *}$ \\
Ca & $(+) 0.831^{*}$ & $(-) 0.809^{*}$ & $(-) 0.200$
\end{tabular}

(+) direct (-) inverse correlation NS: non-significant ${ }^{*} \mathrm{P} \leq 0.05 \quad{ }^{* *} \mathrm{P} \leq 0.01 \quad{ }^{* * *} \mathrm{P} \leq 0.001$

Table 8. Effect of foliar application of putrescine (Put) at $0,0.1$ and $0.2 \mathrm{mM}$ on the seed and oil yield of sunflower plants under two different irrigation levels during the seasons of 2014 and 2015

\begin{tabular}{|c|c|c|c|c|c|c|}
\hline \multirow[b]{2}{*}{$\begin{array}{l}\text { Putrescine } \\
\text { concentration }\end{array}$} & \multicolumn{3}{|c|}{2014} & \multicolumn{3}{|c|}{2015} \\
\hline & $\begin{array}{c}\text { Well- } \\
\text { watered }\end{array}$ & $\begin{array}{c}\text { Water - } \\
\text { stressed }\end{array}$ & Mean & $\begin{array}{c}\text { Well- } \\
\text { watered }\end{array}$ & $\begin{array}{l}\text { Water - } \\
\text { stressed }\end{array}$ & Mean \\
\hline \multicolumn{7}{|c|}{ Seed weight $\left(\right.$ g. head $\left.^{-1}\right)$} \\
\hline Control (distilled water) & $32.9 a b$ & $20.2 \mathrm{c}$ & $26.6 \mathrm{~B}$ & $36.4 \mathrm{~b}$ & $23.0 \mathrm{~d}$ & $29.7 \mathrm{~B}$ \\
\hline $0.1 \mathrm{mM}$ & $39.4 \mathrm{a}$ & $25.9 \mathrm{bc}$ & $32.7 \mathrm{~A}$ & $42.2 \mathrm{a}$ & $26.8 \mathrm{~cd}$ & $34.5 \mathrm{~A}$ \\
\hline $0.2 \mathrm{mM}$ & $41.6 \mathrm{a}$ & $28.1 \mathrm{bc}$ & $34.9 \mathrm{~A}$ & $44.9 \mathrm{a}$ & $29.6 \mathrm{c}$ & $37.2 \mathrm{~A}$ \\
\hline Mean & $38.0 \mathrm{~A}^{\prime}$ & 24.7 B' & & $41.2 A^{\prime}$ & 26.5 B' & \\
\hline \multicolumn{7}{|c|}{ Seed yield (ton. fed ${ }^{-1}$ ) } \\
\hline Control (distilled water) & $0.665 a b c$ & $0.346 \mathrm{~d}$ & $0.506 \mathrm{~B}$ & $0.737 \mathrm{~b}$ & $0.393 \mathrm{~d}$ & $0.565 \mathrm{C}$ \\
\hline $0.1 \mathrm{mM}$ & $0.745 \mathrm{ab}$ & $0.535 \mathrm{c}$ & $0.640 \mathrm{~A}$ & $0.798 a b$ & $0.554 \mathrm{c}$ & $0.676 \mathrm{~B}$ \\
\hline $0.2 \mathrm{mM}$ & $0.832 \mathrm{a}$ & $0.586 \mathrm{bc}$ & $0.709 \mathrm{~A}$ & $0.897 \mathrm{a}$ & $0.601 \mathrm{c}$ & $0.749 \mathrm{~A}$ \\
\hline Mean & $0.747 A^{\prime}$ & 0.489 B' $^{\prime}$ & & $0.811 A^{\prime}$ & $0.516 B^{\prime}$ & \\
\hline \multicolumn{7}{|c|}{$\%$ Oil } \\
\hline Control (distilled water) & $38.71 \mathrm{~b}$ & $34.19 \mathrm{c}$ & $36.45 \mathrm{~B}$ & $37.52 \mathrm{~b}$ & $33.55 \mathrm{~d}$ & $35.53 \mathrm{~B}$ \\
\hline $0.1 \mathrm{mM}$ & $40.17 a b$ & $35.45 \mathrm{c}$ & $37.81 \mathrm{~A}$ & $41.42 \mathrm{a}$ & $36.03 c$ & $38.72 \mathrm{~A}$ \\
\hline $0.2 \mathrm{mM}$ & $41.30 \mathrm{a}$ & $35.51 \mathrm{c}$ & $38.40 \mathrm{~A}$ & $41.34 \mathrm{a}$ & $35.70 \mathrm{c}$ & $38.52 \mathrm{~A}$ \\
\hline Mean & $40.06 A^{\prime}$ & $35.05 \mathrm{~B}^{\prime}$ & & $39.77 \mathrm{~A}^{\prime}$ & $35.09 \mathrm{~B}^{\prime}$ & \\
\hline \multicolumn{7}{|c|}{ Oil yield $\left(\mathrm{Kg} \mathrm{fed}^{-1}\right)$} \\
\hline Control (distilled water) & $257.7 \mathrm{bc}$ & $118.3 \mathrm{~d}$ & $188.0 \mathrm{~B}$ & $276.3 b$ & $131.9 \mathrm{~d}$ & 204.1 B \\
\hline $0.1 \mathrm{mM}$ & $299.1 \mathrm{ab}$ & $189.9 \mathrm{c}$ & $244.5 \mathrm{~A}$ & $330.4 \mathrm{a}$ & $199.5 \mathrm{c}$ & $264.9 \mathrm{~A}$ \\
\hline $0.2 \mathrm{mM}$ & $343.1 \mathrm{a}$ & $208.9 c$ & $276.0 \mathrm{~A}$ & $361.8 \mathrm{a}$ & $214.4 \mathrm{c}$ & $288.1 \mathrm{~A}$ \\
\hline Mean & $299.9 A^{\prime}$ & $172.3 \mathrm{~B}^{\prime}$ & & $322.8 \mathrm{~A}^{\prime}$ & 182.0 B' & \\
\hline
\end{tabular}

Means followed by different letters are significantly different at $P \leq 0.05$ according to Duncan's multiple range test

As for the effect of foliar application of Put on seed and oil yield attributes, it was noticed that the treatments of Put at 0.1 or $0.2 \mathrm{mM}$ enhanced significantly $(P \leq 0.05)$ all the previous traits under the two examined irrigation levels compared to the untreated plants in both seasons. It is well documented that PAs are involved in a wide array of molecular and physiological pathways in plant cell which related directly or indirectly to plant growth and development (Kaur-Sawhney et al 2003).
They also play essential and specific roles with regulatory functions in plant abiotic stress tolerance (Bouchereau et al 1999 and Alcázar et al 2010).

In this study, the growth in terms of fresh and dry weights of leaves and stem, seed yield and its components as well as, several physio-biochemical aspects were positively affected by the treatments of Put. These results may explain the increases in all the previous traits by both examined concentrations of Put compared to the untreated plants. 

plants by modifying of some physio-biochemical parameters

\section{CONCLUSION}

According to the results of this study, it can be concluded that reducing the irrigation level negatively affected growth, LRWC, seed and oil yield of sunflower plants as compared to the well-irrigated ones. These decreases were associated with several changes in the osmolytes including proline, soluble sugars and nutrients ( $\mathrm{K}$ and $\mathrm{Ca}$ ). The foliar application of Put especially at $0.2 \mathrm{mM}$ positively affected most of previous parameters leading to improve the growth and yield of sunflower plants under both examined irrigation levels.

\section{REFERENCES}

Abbaspour, H., Saeidi-Sarb, S., Afsharia, H. and Abdel-Wahhab, M.A. 2012. Tolerance of Mycorrhiza infected Pistachio (Pistacia vera L.) seedling to drought stress under glasshouse conditions. J. of Plant Physiology, 169, 704709.

Alahdadi, I., Oraki, H. and Khajani, F.P. 2011. Effect of water stress on yield and yield components of sunflower hybrids. African J. of Biotechnology, 10(34), 6504-6509.

Alcázar, R., Altabella, T., Marco, F., Bortolotti, C., Reymond, M., Koncz, C., Carrasco, P. and Tiburcio, A.F. 2010. Polyamines: molecules with regulatory functions in plant abiotic stress tolerance. Planta 231,1237-1249.

Ali, Q., Ashraf, M. and Anwar, F. 2009. Physicochemical attributes of seed oil from drought stressed sunflower (Helianthus annuus L.) plants. Grasas Y Aceites, 60(5), 475-481.

Anh, T. P.T, Flood, C.B., da Silva, J.V., Justin, A.M. and Mazliak, P. 1985. Effects of water stress on lipid metabolism in cotton leaves. Phytochemistry, 24(4), 723-727.

A.O.A.C. 2000. Official Methods of Analysis of Association of Official Analytical Chemist. $14^{\text {th }}$ ed Washington, D.C. USA.

Arshad, M. and Amjad, M. 2012. Medicinal Use of Sunflower Oil and Present Status of Sunflower in Pakistan: A Review Study Sci., Tech. and Dev., 31(2), 99-106.

Aziz, A., Martin-Tanguy, J. and Larher, F. 1999. Salt stress-induced proline accumulation and changes in tyramine and polyamine levels are linked to ionic adjustment in tomato leaf discs. Plant Science, 145, 83-91.

Bates, L., Waldren, R.P. and Teare, I.D. 1973. Rapid determination of free proline for waterstress studies. Plant and Soil, 39, 205-207.
Blum, A. 2011. Drought resistance - is it really a complex trait?. Functional Plant Biology, 38, 753-757.

Borell, A., Carbonell, L., Farras, R., PuigParellada, P. and Tiburcio, A.F. 1997. Polyamines inhibit lipid peroxidation in senescing oat leaves. Physiol. Plant, 99, 385-90.

Bouchereau, A., Aziz, A., Larher, F. and MartinTanguy, J. 1999. Poly-amines and environmental challenges: recent development. Plant Sci., 140, 103-125.

Chow, P.S. and Landhäusser, S.M. 2004. A method for routine measurements of total sugar and starch content in woody plant tissues. Tree Physiology, 24, 1129-1136.

Cottenie, A., Verloo, M., Kiekens, L., Velgh, G. and Camerlynk, R. 1982. Chemical analysis of plants and soils. State Univ. Ghent, Belgium, $63,44-45$.

Da Silva, D., Favreau, R., Auzmendi, I. and DeJong, T.M. 2011. Linking water stress effects on carbon partitioning by introducing a xylem circuit into L-PEACH. Ann. Bot., 108, 1135-1145.

Farooq, M., Wahid, A. and Lee, D.J. 2009. Exogenously applied polyamines increase drought tolerance of rice by improving leaf water status, photosynthesis and membrane properties. Acta Physiol. Plant 31, 937945.

Farooq, M., Hussain, M., Wahid, A. and Siddique, K.H.M. 2012. Drought stress in plants: an overview. In: Aroca, R. (Ed.), Plant Responses to Drought Stress. Springer, Berlin Heidelberg, pp. 1-33.

Galston. A.W. and Sawhney, R.K. 1990. Polyamines in plant physiology. Plant Physiol., 94, 406-410.

Gigon, A., Matosy, A., Laffray, D., Fodil, Y. and Pham-Thi, A. 2004. Effect of drought stress on lipid metabolism in the leaves of Arabidopsis thaliana (Ecotype Columbia). Annals of Botany, 94, 345-351.

Gilroy, S., Read, N.D. and Trewavas, A.J. 1990. Elevation of cytoplasmic calcium by caged calcium or caged inositol trisphosphate initiates stomatal closure. Nature, 346, 769-771.

Groppa, M.D., lanuzzo, M.P., Tomaro, M.L. and Benavides, M.P. 2007. Polyamine metabolism in sunflower plants under long-term cadmium or copper stress. Amino Acids 32, 265-275.

Gupta, S., Agarwal, V.P. and Gupta, N.K. 2012. Efficacy of putrescine and benzyladenine on photosynthesis and productivity in relation to 
drought tolerance in wheat (Triticum aestivum L.). Physiol. Mol. Biol. Plants 18, 331-336.

Hanafy Ahmed, A.H., Darwish, E. and Alobaidy, M.G. 2017. Impact of Putrescine and 24epibrassinolide on Growth, Yield and Chemical Constituents of Cotton (Gossypium barbadense L.) Plant Grown under Drought Stress Conditions. Asian J. of Plant Sci., 16(1), 9-23.

Hare, P.D. and Cress, W.A. 1997. Metabolic implications of stress-induced proline accumulation in plants. Plant Growth Regulation, 21, 79-102.

He, L.X., Nada, K., Kasukabe, Y. and Tachibana, S. 2002. Enhanced susceptibility of photosynthesis to low-temperature photoinhibition due to interruption of chill induced increase of Sadenosylmethionice decarboxylase activity in leaves of spinach (Spinacia oleracea L.). Plant Cell Physiology, 43, 196-206

Ibrahim, M.F.M., Bondok, A.M., Al-Senosy, N.K. and Younis, R.A.A. 2015. Stimulation Some of Defense Mechanisms in Tomato Plants under Water Deficit and Tobacco mosaic virus (TMV). World J. of Agric. Sci., 11(5), 289-302.

Ibrahim, M.F.M. and Ibrahim, H.A. 2016a. Assessment of Selenium Role in Promoting or Inhibiting Potato Plants under Water Stress. J. of Horticultural Sci. \& Ornamental Plants, 8(3), 125-139.

Ibrahim, M.F.M., Faisal, A. and Shehata, S.A. 2016b. Calcium Chloride Alleviates Water Stress in Sunflower Plants Through Modifying Some Physio-Biochemical Parameters. American Eurasian J. Agric. \& Environ. Sci., 16(4), 677-693.

Iqbal, M. and Ashraf, M. 2005. Changes in growth photosynthetic capacity and ionic relations in spring wheat (Triticum aestivum L.) due to presowing seed treatment with polyamines. Plant Growth Regulation, 46, 19-30.

Jackson, M.L. 1967. Soil Chemical Analysis Prentice Hall of India Pvt. Ltd., New Delhi; 205 p.

Jiang, X.Y., Song, J., Fan, H. and Zhao, K.F. 2000. Regulations of exogenous calcium and spermidine on ion balance and polyamine levels in maize seedlings under $\mathrm{NaCl}$ stress. Acta Phytophysiologica Sinica, 26(6), 539-544.

Jiménez-Bremont, J.F., Becerra-Flora, A., Hernández-Lucero, E., Rodríguez-Kessler, M., AcostaGallegos, J.A. and Ramírez-Pimentel, J.G. 2006. Proline accumulation in two bean cultivars under salt stress and the effect of polyamines and ornithine. Biologia Plantarum 50, 763-766.
Karimi, Z. 2016. Putrescine Foliar Application effect on Physiologic and Morphologic Characteristics of Wheat (Tiriticum aestivum var sw-82-9) under Water Deficit Stress. Biological Forum, 8(1), 532-539.

Kaur-Sawhney, R., Tiburcio, A.F., Altabella, T. and Galston, A.W. 2003. Polyamines in plants: An overview. J. Cell Mol. Biol., 2, 1-12.

Lahiri, K., Chattopadhyay, S. and Ghosh, B. 2004. Correlation of endogenous free polyamine levels with root nodule senescence in different genotypes in Vigna mungo L. J. Plant Physiol., 161, 563-571.

Misra, N. and Gupta, A.K. 2005. Effect of salt stress on proline metabolism in two high yielding genotypes of green gram. Plant Sci., 169, 331-339.

Navakoudis, E., Lütz, C., Langebartels, C., LützMeindl, U. and Kotzabasis, K. 2003. Ozone impact on the photosynthetic apparatus and the protective role of polyamines. Biochimica et Biophysica Acta-Bioenergetics, 1621, 160169.

Okazaki, Y. and Saito, K. 2014. Roles of lipids as signaling molecules and mitigators during stress response in plants. The Plant J. 79, 584-596.

Ramel, F., Sulmon, C., Gouesbet, G. and Couee, I. 2009. Natural variation reveals relationships between pre-stress carbohydrate nutritional status and subsequent responses to xenobiotic and oxidative stress in Arabidopsis thaliana. Ann. Bot. London, 104,1323-1337.

Roy, P., Niyogi, K., SenGupta, D.N. and Ghosh, B. 2005. Spermidine treatment to rice seedlings recovers salinity stress-induced damage of plasma membrane and PM-bound $\mathrm{H}^{+}$ATPase in salt-tolerant and salt-sensitive rice cultivars. Plant Sci., 168, 583-591.

Saleem, N.A., Malik, A.U., Anwar, R. and Farooq, M. 2008. Exogenous application of polyamines improves fruit set, yield and quality of sweet oranges. Acta Hortic., 774, 187194.

Saraswathi, S.G. and Paliwal, K. 2011. Drought induced changes in growth, leaf gas exchange and biomass production in Albizia lebbeck and Cassia siamea seedlings. J. Environ. Biol., 32, 173-178.

SAS Institute Inc., 1988. SAS/STAT User's Guide: Release 6.03 ed. SAS Inst. Inc., Cary, NC.

Schuber, F. 1989. Influence of polyamines on membrane functions. Biochem J. 260(1),1-10. 
Smeekens, S., Ma, J.K., Hanson, J. and Rolland, F. 2010. Sugar signals and molecular networks controlling plant growth. Curr. Opin. Plant Biol., 13, 274-279.

Smirnoff, N. 1993. The role of active oxygen in the response of plants to water deficit and desiccation. New Phytol., 125, 27-58.

Suping, W., Yongxia, J., Shirong, G. and Guoxian, Z.. 2007. Effects of polyamines on $\mathrm{K}$ ${ }^{+}, \mathrm{Na}^{+}$and $\mathrm{Cl}^{-}$content and distribution in different organs of cucumber (Cucumis sativus L.) seedlings under $\mathrm{NaCl}$ stress. Front. Agric. China, 1(4), 430-437.

Taiz, L. and Zeiger, E. 2002. Plant Physiology, $3^{\text {rd }}$ Edition. Sinauer Associates Inc., Sunderland, MA, USA. pp. 539-558.

Tamai, T., Inoue, M., Sugimoto, T., Sueyoshi, K., Shiraishi, N. and Ofi, Y. 1999. Ethyleneinduced putrescine accumulation modulates $\mathrm{K}^{+}$partitioning between roots and shoots in barley seedlings. Physiologia Plantarum, 106, 296-301.

Tassoni, A., Antognoni, F. and Bagni, N. 1996. Polyamine Binding to Plasma Membrane Vesicles Isolated from Zucchini Hypocotyls. Plant Physiol. 110, 817-824.

Tezara, W., Mitchell, V.J., Driscoll, S.D. and Lawlor, D.W. 1999. Water stress inhibits plant photosynthesis by decreasing coupling factor and ATP. Nature 401, 914-917.
Tiburcio, A.F., Kaur-Sawhney, R. and Galston, A.W. 1993. Spermidine biosynthesis as affected by osmotic-stress in oat leaves. Plant Growth Regul., 13, 103-109.

Unyayar, S., Keles, Y. and Unal, E. 2004. Proline and $A B A$ levels in two sunflower genotypes subjected to water stress. Bulg. J. Plant Physiol. 30(3/4), 34-47.

Velikova, V.B., Yordanov, I.T., Georgieva, K.M. Tsonev, T.D. and Goltsev, V. 1998. Effects of exogenous polyamines applied separately and in combination with simulated acid rain on functional activity of photosynthetic apparatus, $\mathbf{J}$. Plant Physiol., 153, 299-307.

Zhang, Y., Zhong, C.L., Chen, Y., Chen, Z., Jiang, Q.B. and $\mathbf{W u}, C$. 2010. Improving drought tolerance of Causarina equisetifilia seedlings by arbuscular mycorrhizal under glasshouse conditions. New Forests., 40, 261271.

Zhao, F.G. and Qin, P. 2004. Protective effect of exogenous polyamines on root tonoplast function against salt stress in barley seedlings. Plant Growth Regulation, 42(2), 97-103.

Zhao $\mathbf{H}$ and Yang, H. 2008. Exogenous polyamines alleviate the lipid peroxidation induced by cadmium chloride stress in Malus hupehensis Rehd. Sci. Hortic., 116, 442-447. 